\title{
A GLOBALIZAÇÃO E A CRISE NO DIREITO: REPENSANDO A ÉTICA E A MORAL NO ESTADO PÓS-MODERNO
}

DENDASCK, Carla ${ }^{1}$

SILVA, Adonias Osias ${ }^{2}$

DENDASCK, Carla; SILVA, Adonias Osias - A globalização e a crise no direito: Repensando a ética e a moral no Estado Pós-Moderno - Revista Científica Multidisciplinar Núcleo do Conhecimento - Vol. 01, Ed. 03, Ano. 01, Março de 2016 , pp. 98-119 - ISSN: 2448-0959

\section{RESUMO}

O presente ensaio tem por escopo uma análise crítica sobre a globalização tecnológica e econômica e os seus impactos no direito positivo, com sua lógica normativista formal face a contextos que se apresentam cada vez mais complexos e mutáveis. Partindo dessa premissa, pretende-se avaliar como a ética e a moral podem servir de norte nessa mudança de paradigma que se faz necessária para uma aplicação do direito que melhor atenda aos anseios do cidadão em uma sociedade em constante mudanças. Busca-se analisar o papel do direito sob esse novo viés de globalização e a sua relevância para o homem hodierno.

Palavras Chaves: Ética. Moral. Globalização. Direito

${ }^{1}$ Doutora em Psicanálise, Pós- Doutorando em Psicanálise Clínica, Mestranda em Bioética- Diretora do Centro de Pesquisa e Estudos Avançados- E-mail: prof.dra.csd@hotmail.com.

${ }^{2}$ Advogado, Pós- graduado em Direito Tributário; Mestrando em direito na Escola Paulista de Direito; adonias.silva@unifesp.br. 


\section{INTRODUÇÃO}

É de sabença geral que a trajetória do homem no planeta, iniciando nas cavernas até o homo sapiens, quando o homem passou a tomar consciência de sua inteligência e instituiu sua liberdade para vencer os obstáculos que sempre atravessaram seu caminho, sempre foi marcada pela participação do homem na construção do direito e da justiça.

Mesmo nos primórdios da civilização, quando ainda não se tinha uma ideia aperfeiçoada de direito e de justiça como temos nos dias atuais, o homem sempre lutou para ser o ator da sua própria história e dentro dessa toada passou a ser um ser político e moral, que agia dentro do seu conceito de ética e moralidade.

Aliás, pode-se diferenciar o homem dos demais seres vivente exatamente por conta do seu desenvolvimento intelectual, que por sua vez está diretamente relacionado à sua conduta em sociedade, ou seja, no seu procedimento moral que é demonstrado por meio de suas atitudes na convivência coletiva com os seus pares, o que não sói acontecer com os demais seres vivos, que agem simplesmente por instinto. Essa sua postura entre os demais semoventes da natureza é que lhe dá lugar de destaque como ser social dominador (REALE, 1994).

Desde os costumes sociais transmitidos de pai para filho as relações dos grupos sociais evoluíram de simples paradigmas de convivência até se chegar a estruturação de comandos mais sólidos tais como o direito positivado, e tudo isso como consequência do caráter eminentemente gregário do ser humano que a partir da sua convivência social fez exsurgir o direito, como fenômeno social de sua própria cultura, com suas regras e sanções.

E para ratificar essa realidade há um brocardo em latim que diz: "ubi est societas, ibi ius" (onde houver sociedade, aí estará o direito). Esse é o ponto de partida do presente ensaio, uma vez que a sociedade evoluiu, tornou-se global, e o direito positivo com sua normatividade formal, ao que parece, já não consegue atender aos 
anseios desse homem moderno que em meio a um mundo globalizado segue em sua eterna jornada em busca da justiça.

A globalização, que veio de mãos dadas com a revolução tecnológica e as mudanças econômicas, após vencida sua primeira fase de instalação, qual seja, a integração dos mercados mundiais, agora nos apresenta um novo desafio que são os desdobramentos e os impactos nas instituições jurídicas. O grande desafio é saber qual a eficácia e o alcance dos institutos jurídicos e de seus instrumentos legais para essa nova realidade do homem globalizado.

Ao lado disso, não se pode olvidar o papel da ética e da moral para o direito moderno, bases de uma sociedade justa e correta. Tal realidade pode ser constatada pelo simples fato de que, na prática, a aplicação concreta do direito faz-se por intermédio da justiça distribuída por um homem - o juiz - a quem o sistema jurídico incumbe 0 honroso mister de solucionar a controvérsia entre as partes litigantes em busca de uma sentença.

No cotejo do trâmite processual em busca da sentença o que se percebe é que são postas em confronto não apenas as normas jurídicas, senão todos os princípios de ética e moral que a lei processual exige não apenas dos litigantes como também do próprio juiz. O ponto nevrálgico é saber como ser ético em meio a corrupção degenerada trazida no seio da globalização e seus sistemas tecnológicos, onde se pode fraudar desde uma simples escolha de síndico de condomínio até uma eleição para escolha dos nossos governantes.

A globalização econômica impõe ao homem o dever de ser rico, de ter, de possuir a todo custo, e as inovações tecnológicas são os trilhos que conduzirão a locomotiva da desonestidade, sob o vão pretexto de que os fins justificam os meios, afastando cada vez mais os seres humanos dos valores éticos e morais recebidos de berço. $E$ imbricado nesse sistema da "lei de Gerson", da facilidade a qualquer custo, encontrase o direito, com todas as suas vertentes e determinantes. 
É sobre essa crise no direito que se pretende tratar no presente texto, levando em conta os aspectos da globalização, que tornou o mundo em uma aldeia global, e levou consigo os valores da ética e da moral que nos foram transmitidos pelos nossos patriarcas. Vivemos hoje em contextos cada vez mais complexos e mutáveis, que clamam por um direito contextualizado, um direito que atenda às necessidades do homem atual, que já não são mais as mesmas do homem inserido no contexto do século passado.

O que se pode afirmar de concreto é que o Estado e o direito, nos moldes tradicionais que estão implantados na sociedade hoje, não se adequam às evoluções sociais vividas pelo homem dentro da sociedade. Hoje, mais que nunca, o direito precisa tomar outros rumos se quiser atender aos anseios desse homem globalizado. $O$ direito tem que se voltar para meios alternativos, ou seja, o direito deve ser um direito de negociações, de mesas redondas, de arbitragem e mediação.

O certo é que os caminhos que nos trouxeram até aqui não serão os mesmos que nos levarão daqui para adiante. E por conta dessa realidade é válido analisar até que ponto o direito positivado, com uma lógica formal e inflexível, pode atender a contento os anseios desse homem globalizado, em especial no que concerne ao aspecto ético e moral. Há necessidade de se manter a ética e a moral sem perder de vista o direito justo e sua correta aplicação ao caso concreto.

\section{A GLOBALIZAÇÃO NO ESTADO MODERNO}

A história tem mostrado que o homem sempre lutou por melhorias em suas condições de vida. Os conglomerados humanos já tomavam forma de cidades há cerca de 3.500 a.C e do seu contexto social emergiam os guerreiros com suas primitivas armas que eram forjadas para defesa do grupo social. A partir dessa realidade surgiam os construtores de suas mansardas, os que dominavam a utilização da água, e aqueles, que com sua sabedoria aprenderam a interpretar os fenômenos naturais e se tornaram seus sacerdotes e primeiros juízes. 
A partir desse desenvolvimento primário o homem e a sociedade desenvolveram-se de várias maneiras e em diversos estágios, que não convém aqui analisa-los, uma vez que o presente papel não se presta a esse desiderato. Entretanto, vale destacar aqui apenas os abolutismos que marcaram os primeiros tempos do Estado Moderno, que trouxe como característica o monopólio do uso da violência por parte dos déspotas, que de maneira absoluta detinham o poder a todo custo, sendo não apenas legislador mas também juiz da sua própria vontade.

O estado, visando manter a paz social ameaçada ou violada, proibiu a autotutela e chamou para si a responsabilidade de solucionar os litígios. A partir desse momento - Estado passou a ter a função de aplicar o direito aos casos concretos a ele submetidos e compor os conflitos.

Em decorrência disso surgiu o Estado como detentor da ordem, da lei e da justiça restringindo o campo de atuação dos governantes aos estritos limites da lei, conferindo ao judiciário a competência exclusiva para julgar e dirimir os conflitos, e esse o faz por meio da jurisdição. O vocábulo jurisdição procede da composição de duas palavras: do substantivo latino jus, juris, que significa "direito", mais a terceira conjugação do verbo dicere, que significa "dizer", "afirmar", "expressar". Assim, jurisdição é o poder que o Estado tem de dizer o direito.

Entretanto, a jurisdição é inerte, segundo o brocardo latim: "nemo iudex sine actore; ne procedat iudex officio (não há juiz sem ator; o juiz não procede de ofício). Daí surgiu o art. $2^{\circ}$ do Código de Processo Civil, que assim prolata: "Nenhum juiz prestará a tutela jurisdicional senão quanto a parte ou interessado a requerer, nos casos e formas legais".

Por essa razão, para que o Estado possa oferecer a prestação jurisdicional e exercer seu papel como mediador dos litígios há necessidade que o titular do interesse em conflito na relação jurídica de direito material tenha iniciativa e vá bater às portas do judiciário. Por oportuno, é válido ressaltar que embora o Estado não tenha iniciativa para início da jurisdição, uma vez provocada a função jurisdicional do Estado, o 
processo será desenvolvido por impulso oficial até sua ultimação com uma sentença que ponha fim à lide provocada.

Com o crescimento populacional e o crescimento econômico, tecnológico e social, a demanda de cidadãos que batem às portas do judiciário são proporcionalmente maiores que as respostas dadas àqueles que buscam uma resposta às suas demandas e litígios. E o resultado disso é que o judiciário, que já não atende às demandas ali levadas, passa a um ativismo judicial que não corresponde aos anseios do cidadão.

Hoje, com a globalização, os problemas enfrentados pela sociedade são completamente diferentes dos vivenciados pela geração passada e a tendência é um incremento dessas dificuldades, e a certeza que nos resta é que o judiciário não está preparado para as mudanças que se apresentam para a próxima geração, que trataremos nas linhas seguintes.

Quando se fala em globalização o que se tem em mente é uma análise séria dos processos e mudanças inter-relacionadas e que estão acontecendo no cenário mundial, e com isso todo o modo de pensar, agir e viver da sociedade está sendo alterado substancialmente. Tais mudanças afetam não apenas as estruturas econômicas e sociais, senão que interferem diretamente no modo de produção jurídica atual e, como resultado, na forma de pensar e fazer o direito.

O primeiro ponto que não se pode deixar de mencionar é a questão da soberania do Estado-nação face ao crescimento do multinacionalismo e transnacionalismo. Com o aumento das empresas multinacionais e o surgimento desenfreado de agentes supranacionais e transnacionais trazidos pela globalização, o Estado-nação vê sua força mitigada no que respeita a regulamentação e estruturação das regulações econômicas, bem como no que tange a proteção do indivíduo e da sociedade. O que antes era de competência exclusiva do estado-nação, a partir da globalização passará a ser alvo e interesse de outras instituições transnacionais e multinacionais. 
As empresas multinacionais, com sua capacidade para expansão, tanto da produção quanto outras operações por todo o mundo, em que pese sua importância para o desenvolvimento econômico e social, impõem ao direito um modo de pensar completamente diferente dos moldes trazidos do século passado e que tem se perpetuado na história. A facilidade com que essas empresas têm para mudar suas fábricas de um país para o outro bem como seu potencial de negociação mundial, passa a exigir do direito uma visão global e mais aberta e menos sistemática, fechada e localizada como a atual.

A relevância dessas empresas para a economia mundial conduz a uma mudança de foco para as relações sociais, com toda sua complexidade, passando a exigir do jurista não apenas a visão nacional, porém, um olhar 'além das fronteiras', ou seja, um olhar global. Até mesmo porque virou lugar comum se ouvir que "o mundo é uma aldeia global", significando com isso que as cercas, os muros e os limites que nos separavam dos nossos vizinhos, agora já não mais podem ser vislumbrados.

Tal realidade afeta o direito em todos os níveis e tem seus desdobramentos nos valores éticos, morais e de bom comportamento que se exige do cidadão inserido nesse contexto social globalizado. Expostos a todos os riscos trazidos pela globalização, esse cidadão, que procura no judiciário uma resposta à sua demanda, não encontra no direito mais que conceitos e institutos pré-estabelecidos, formalmente impostos e determinados, que não consegue atender às suas necessidades dentro dessa complexidade global.

Por essa razão, pode-se afirmar que a globalização aponta para uma mudança no direito civil, penal, empresarial, administrativo e, acima de tudo, no direito internacional, que precisa se adequar constantemente para o atendimento de situações novas e inusitadas que até algum tempo atrás não se pensava sequer existir, tais como o comércio global e a união de mercados financeiros que, não obstante sua flexibilização para criação de capitais unidos globalmente e a facilitação do livre fluxo de investimento sem fronteiras, não deixa de ser uma realidade nova e difusa para o direito atual. 
Um outro fator que deve ser pensado nesse mundo globalizado é a questão do crescimento dos blocos econômicos regionais, pois isso afeta diretamente o modus operandi do direito como está posto em nossa sociedade. O que é mais comum hoje, e que tem aumentado a cada ano que passa, é o intercâmbio entre os blocos regionais de comércio, ou seja, a diminuição das barreiras comerciais entre as nações. Basta lembrar de siglas como ALCA, MERCOSUL, UEA, apenas para citar alguns desses blocos que se unem com afinidades comerciais. $O$ certo é que hoje o comércio internacional é uma realidade e os conceitos neoliberais, que eram mais hegemônicos, estão abrindo as portas de muitas nações outrora fechadas ao diálogo, como é o caso da Europa Oriental, a antiga União Soviética e, porque não dizer, com reflexos positivos na China.

O livre comércio internacional e a ênfase exacerbada que se dá aos mercados privados, de certo modo descentraliza e reduz o papel governamental, que sempre foi o regulador da economia. Essa mudança à livre negociação é de tamanha monta que influenciou diretamente a política econômica do "Tio Sam", bem como a política econômica europeia em geral, levando à criação de entidades como o FMI, o BIRD (assim como os bancos regionais e o GATT), espraiando seus efeitos ao redor do mundo globalizado.

E se todas essas mudanças não fossem suficientes para desenhar o gráfico da sociedade atual, ainda se pode falar na tendência mundial à democratização, à proteção dos direitos humanos, levando um interesse muito maior à seara do direito, dada a função jurisdicional do Estado inicialmente apontada. Paralelo às manifestações gritantes por mudanças econômicas, percebe-se um esforço tremendo, a nível internacional, para a criação de políticas liberais, que visem tutelar os direitos humanos individuais, bem como o controle da arbitragem governamental e o fortalecimento dos institutos jurídicos que venham realmente atender ao pedido de prestação jurisdicional do cidadão, face aos seus interesses difusos e coletivos.

Paralelo a tudo isso encontramos ainda as ONGs, que são os protagonistas transnacionais e supranacionais que surgem nesse cenário visando tutelar os direitos humanos, o direito dos desvalidos, o direito a um meio ambiente sustentável, o direito 
das populações indígenas, o direito das minorias étnicas, a questão dos homo afetivos na sociedade, apenas para citar algumas delas. Não se pode mais olvidar que todas essas questões fazem parte do dia a dia do cidadão e a sociedade anseia por uma resposta satisfatória e que venha ao encontro desse homem moderno que, ao que parece, foi convidado a sair da caverna, entretanto não the foi dado os meios necessários para seguir em frente, razão pela qual continua absorto a tudo o que vê ao seu redor, sentindo-se impotente e despreparado para enfrentar essa nova realidade.

Ao analisar toda essa problemática global, fica patente que o direito não tem envidado esforços à canalização e condução dos conflitos e embates surgidos no seio da sociedade, razão pela qual há que se falar não apenas em uma mudança radical e urgente, senão em uma total adequação de conceitos tradicionalmente utilizados, de tal modo que, do mesmo modo como o homem saiu da caverna, o direito também faça o mesmo caminho e venha ao encontro desse homem moderno em meio a uma sociedade caótica, um mundo globalizado, e uma vivência de conflitos generalizados em todos os níveis.

\section{DIREITO POSITIVISTA E LÓGICA FORMAL}

Não é possível falar em positivismo na seara jurídica sem se atrelar à figura de Hans Kelsen. Na realidade, embora seja considerado o pai do positivismo vale destacar $a b$ initio que toda doutrina positivista foi sendo construída ao longo dos anos e teve seu papel preponderante para o desenvolvimento do direito enquanto ciência jurídica.

Para Kelsen, o direito deveria ser entendido como norma, divorciada de qualquer concepção social ou valorativa. Exatamente por pensar desse modo é que o ponto central da sua obra, conhecida como Teoria Pura do Direito, é a libertação dessa ciência jurídica de todos os elementos que, pela ótica de Kelsen, não lhe são próprios. Ao propor essa cisão o jurista alemão visa dar à ciência jurídica uma autonomia própria, totalmente livre de elementos que não pertençam à sua alçada. 
Para Kelsen a ciência jurídica pura deve ser inconfundível com a psicologia, a sociologia, a política e a moral. Embora tais ciências se relacionem de algum modo com o direito e cruzem seu caminho na maioria das vezes, mesmo assim a ciência jurídica não pode ser impregnada com tais conceitos alheios à sua área de atuação. Tal entendimento, embora soe estranho aos ouvidos, tem seu valor quando se quer falar de justiça, pois se utilizando de uma linguagem precisa e rigidamente lógica, Kelsen abstraiu do conceito do Direito a ideia de justiça.

A justiça está sempre e invariavelmente imbricada com os valores (sempre variáveis) adotados por aquele que a invoca (seja por argumentos sociológicos, psicológicos ou morais), não cabendo num conceito de Direito universalmente válido, por conta da imprecisão e fluidez de significado, pois o que é justo para um determinado contexto ou sociedade não seria justo para outro.

$\mathrm{Na}$ visão de Kelsen o direito se restringe a um conjunto de normas representadas por prescrições que revelam a categoria do "dever ser", e desse modo relega os fatos a uma escala de jurídico ou antijurídico. Com isso se percebe claramente que Kelsen cria uma deontologia baseada na distinção entre ser e dever-ser. Em outras palavras, Kelsen traça uma distinção entre as coisas como são e as coisas como devem ser, e essa relação entre "o ser" e o "dever-ser" desemboca em duas vertentes distintas, e que são cruciais na sua concepção do Direito. A primeira dessas vertentes diz respeito ao fato de que essa distinção entre ser e dever-ser serve para diferenciar entre as duas modalidades em que se pode estudar direito: a primeira é a visão do direito como ele é, e a segunda é a visão do direito como ele deve ser. A segunda vertente dá conta que essa distinção também serve para fazer um marco divisório entre o reino dos fatos - relacionado ao ser - e o reino das normas - relacionado ao dever-ser. Assim sendo, cria-se a seguinte equação: o não cumprimento da obrigação (a ausência do fato obrigacional), implica em sanção (dever ser). Em palavras mais claras: ao não cumprimento (dever), deve haver penalidade (sanção estabelecida pela norma).

Neste contexto, Kelsen observa que a norma é um produto da vontade, elaborada com a finalidade de regular a conduta humana e que funciona como um esquema de 
interpretação. Aqui se faz necessário destacar que para o positivismo a norma tem validade não pelo sentido de ser justa, mas pelo simples fato de estar ligada a outra norma considerada superior que ele denomina de norma fundamental. É a partir desse conceito metodológico da norma fundamental que o jurista consegue criar uma sistematização de toda uma ordem jurídica.

Uma de suas concepções teóricas de maior alcance prático é a ideia de ordenamento jurídico como sendo um conjunto hierarquizado de normas jurídicas estruturadas na forma de uma pirâmide abstrata, pontuada e dominada pela Constituição do Estado, que subordina as demais normas jurídicas de hierarquia inferior (as diversas leis infraconstitucionais e os outros atos normativos). Desta concepção teórica é que se extrai o conceito de rigidez constitucional, o que vem a possibilitar e a exigir um sistema de tutela da integridade da Constituição. Embora haja controvérsias quanto a criação da pirâmide normativa, para efeito do presente ensaio atribui-se a Kelsen.

Outra grande contribuição do jurista para o mundo prático do Direito foi a Constituição da Áustria de 1920, redigida sob a sua inspiração. À sombra da influência do pensamento Kelseniano esta Carta Política Austríaca inovou às anteriores, introduzindo no Direito Positivo o conceito de controle concentrado de constitucionalidade das leis e atos normativos como função jurisdicional a cargo de um tribunal constitucional, incumbido da função exclusiva de guarda da integridade da Constituição.

A partir daí a jurisdição constitucional pode ser seccionada em duas vertentes: a jurisdição constitucional concentrada (controle concentrado da constitucionalidade) e a jurisdição constitucional difusa (controle difuso da constitucionalidade). Este último modo de guarda da Constituição (difuso) já era praticado nos Estados Unidos da América.

No ordenamento jurídico pátrio, sob a égide da Constituição Federal de 1988, a jurisdição constitucional é praticada dos dois modos: o concentrado, por meio de ações próprias da competência do Supremo Tribunal Federal, e o difuso, executado 
nos autos de quaisquer ações (e dos recursos a estas inerentes) da competência de qualquer órgão jurisdicional, sejam juízes ou tribunais.

Portanto, quando se discute Kelsen não se pode perder de vista o foco da questão principal do seu pensamento que é a validade da norma jurídica e a sua hierarquização, sendo esse um dos aspectos mais importantes da sua teoria.

Diante do exposto, percebe-se que o direito positivista é um conjunto de normas que regulam a conduta humana e essas normas, por sua vez, quando legitimamente válidas e descumpridas adquirem poder para estabelecer sanções, pois, em razão da sua estrutura, é caracterizada como uma ordem coercitiva e que só tem validade se estiver umbilicalmente ligada a outra norma.

O grande problema que se apresenta em relação ao positivismo jurídico é que mesmo sendo ele um sistema de normas que regulam a conduta do homem dentro da sociedade, mesmo assim a inflexibilidade do direito positivado não consegue atender aos anseios desse mesmo homem. Nessa esteira vale a pena ressaltar a crítica feita por Dworkin ao positivismo jurídico ao afirmar que o positivismo é tão dogmático que "a lei frequentemente se torna aquilo que o juiz afirma"(DWORKIN, 2003, p. 4). Nessa crítica Ronald Dworkin faz um contraponto ao direito positivista apresentando um modelo teórico que tem como escopo dar uma resposta adequada a questão da interpretação, que ele chama de integridade do direito

Pois bem, esse dogmatismo intolerante do positivismo jurídico, que acaba por reduzir a lei ao pronunciamento de determinados juízes é que culmina por tirar a esperança do cidadão, relegando o direito apenas ao mundo das ideias, aquilo que deveria ser, e não ao mundo real, aquilo que se espera quando se ingressa no judiciário com uma demanda: a concretude da demanda judicial. Não se fala aqui em justiça, pois como já foi mencionado, o positivismo jurídico não tem essa pretensão de justiça, mas simplesmente visa fornecer um conceito universalmente válido de direito, apartado de outras realidades sociais. O que se pretende aqui é que pelo menos a tão almejada prestação jurisdicional seja efetivada de fato e de direito e não apenas teorizada em normas jurídicas, verbalizadas pela toga. 


\section{A ÉTICA E A MORAL NO DIREITO}

Quando se fala em ética e moral no direito não se pode deixar de mencionar que a conduta de um indivíduo em relação ao outro, seja em que contexto social ocorra, nas lutas judiciais levadas a efeito à justiça, sempre tem um forte cunho moral.

A única diferença entre os postulados éticos e morais e o direito é que esse último tem sua força coercitiva regulada pelo ordenamento jurídico, que a todos se sobrepõe com suas regras, ditames e normas definidas, que trazem consigo as sanções passíveis a quem a elas não se submetem.

O jurista positivista Hans Kelsen (2001:36), já mencionado nesse texto, traz uma importante contribuição para a compreensão desse tema ética e moral no direito. Em sua obra "o que é justiça", o sábio alemão assim se expressa:

Embora reconhecendo o direito como a técnica social específica da ordem coercitiva, podemos compará-lo com outras ordens sociais que, em parte, perseguem os mesmos objetivos que o direito, mas por meios diversos. O direito é meio social específico, não um fim. O direito, a moralidade e a religião - todos os três proíbem o assassinato. Mas, o direito faz isso provendo que: se um homem comete assassinato, outro homem, designado pela ordem jurídica, aplicará contra o assassino, certa medida de coerção prescrita pela ordem jurídica. A moralidade limita-se a exigir: não matarás.

É digno de nota que embora a moral não tenha o poder e a força de estabelecer uma sanção pela sua desobediência, como faz o direito, mesmo assim ela não pode ser desprezada pelos estudiosos do direito, uma vez que antes mesmo do direito positivado com suas normas e conceitos a moral já era utilizada pelas sociedades primitivas como meio de nortear e conduzir os relacionamentos no convívio social.

Portanto, a distinção entre a moral e um princípio jurídico é uma linha tênue e que muitas vezes caminham juntas e próximas e que são separadas apenas pelos seus efeitos. Tomemos como exemplo um filho que ao passar pelo pai e recebe um 
cumprimento não retribui na mesma delicadeza, ou até mesmo o destrata, tal comportamento é uma ofensa moral para a qual não existe uma cominação legal. Entretanto, se esse mesmo filho, ao ser cumprimentado pelo pai lhe causa uma lesão corporal, nesse caso comete crime previsto no ordenamento e deve ser punido.

Por essa razão, Chaïm Perelman (1996:289), o grande filósofo de Bruxelas e um dos maiores filósofos do direito do Séc. $X X$, ao tratar desse tema direito e moral, deixou registrado o seguinte:

Tradicionalmente, os estudos consagrados às relações entre direito e a moral insistem, dentro de um espírito kantiano, naquilo que os distingue: o direito rege o comportamento exterior; a moral enfatiza a intenção, o direito estabelece uma correlação entre os direitos e as obrigações, a moral prescreve deveres que não dão origem a direitos subjetivos, o direito estabelece obrigações sancionadas pelo poder; a moral escapa às sanções organizadas. Os juristas, descontentes com uma concepção positivista, estadística e formalista do direito, insistem na importância do elemento moral no funcionamento do direito, no papel que nele desempenham a boa-fé, a má-fé, a intenção maldosa, os bons costumes, e tantas outras noções cujo aspecto ético não pode ser desprezado.

Pelas palavras do erudito filósofo de Bruxelas já se dá para ter uma ideia da dimensão que a moral e a ética desempenham na aplicação do direito para os dias atuais. Vivemos em uma sociedade onde os valores éticos e morais se confundem com os interesses pessoais e particulares, razão pela qual tais valores são cada vez mais relegados a segundo plano, marcas de uma sociedade consumerista, onde o que importa é se atingir os fins, não importando os meios utilizados para tal, fazendo prevalecer o velho brocardo de que os fins justificam os meios.

Pois é exatamente nessa tênue linha entre os valores morais e éticos e os bons costumes que o direito deve palmilhar sua trajetória, uma vez que a sociedade vem perdendo a noção desses valores a cada geração que passa. Na época dos nossos pais a simples palavra empenhada selava um negócio jurídico e era levado a efeito até às ultimas circunstâncias. 
Atualmente, mesmo estando cercado de todas as garantias, de fidúcia e tudo o mais, mesmo assim não se tem mais a real segurança de que o negócio jurídico chegará a termo de um modo são, sem a intervenção do estado exercendo seu papel coator para exigir as regras inicialmente compactuadas.

Diante dessa exigência social que se impõe na atualidade o direito, do modo como se materializa no processo, por meio da decisão do juiz, traz à tona todo o acervo da cultura humana no trato dos interesses dos litigantes em face do estado jurisdicional, que cada vez mais assume seu papel coator delegado pela própria sociedade.

O certo é que no cotejo da prática processual são postos em confronto não apenas as normas jurídicas como também todos os princípios éticos que a lei do processo exige dos litigantes e até mesmo do próprio juiz. Ladeado da liberdade existe toda uma estrutura de lealdade e sinceridade que é exigido por lei nas lides e embates judiciais. O que se deve buscar é não apenas a norma positivada e formal, mas também os valores morais e éticos como elementos essenciais da pretensão jurisdicional buscada.

A sociedade, do modo como está organizada hoje, com todos os instrumentos de controle social e o aumento da informação por meio da tecnologia e o crescimento econômico por conta da globalização, já não se presta a um papel de mera expectadora da justiça. Ao contrário, pela falta que o ordenamento jurídico tem demonstrado, o que se observa hoje, mais que nunca, é uma sociedade querendo fazer justiça com as próprias mãos, tentando preencher esse vácuo deixado pelo judiciário na prestação jurisdicional, mas infelizmente operando da maneira errada, cometendo, muitas vezes, sob o manto da justiça, mais injustiça ainda. Tudo isso por conta desse formalismo jurídico, que busca apenas na técnica e aprimoramento das leis as respostas aos problemas sociais, o que deixa evidente que esse modelo já não é mais suportado pela sociedade moderna.

No tocante a isso é válido ressaltar aqui as palavras do jurista italiano Francesco Carnelutti (2004:60), que exarou: "Se o direito é um instrumento da justiça, nem a técnica nem a ciência bastam para manejá-lo". Fica evidenciado, pelas palavras do 
ínclito jurista italiano que a aplicação prática do direito, que se faz através da justiça levada a efeito nos conflitos judiciais, exige mais que técnicas Jurídicas e manejo de normas para que se faça justiça. A grande questão que não se pode mais ocultar é saber se a aplicação do direto como é feita nos dias atuais, de um modo positivado, pronto e formal, visa realmente a justiça. Percebe-se que na aplicação do direito os problemas práticos levados ao judiciário não encontram resposta ante aos conceitos jurídicos pré-estabelecidos e estritamente formais.

Não foi sem razão que Jhering (2012:322) disse que os problemas práticos não se adaptam bem ao paraíso dos conceitos em que muitos juristas preferem viver. Segundo João Maurício Adeodato (2012:317), propõe-se uma interpretação menos dogmática da obra de Jhering, autor esse que é internacionalmente considerado um dos mais importantes para a dogmática do direito privado.

Diante disso percebe-se que o direito deve caminhar em busca de um equilíbrio entre a visão positivista normativista de Hans Kelsen, onde a decisão do juiz deve ser moldada pela norma posta (daí direito positivo), e a posição mais extremada

proposta pela tópica de Viehweg, para a qual a decisão não deve guardar relação com os textos normativos. Quanto a isso, João Maurício Adeodato (2012:313) escreve com muita propriedade sobre o tema:

A tópica de Viehweg parece levar a uma "abertura" excessiva em relação ao texto normativo, que é considerado apenas expressão de um topos dentre outros. Ao recusar o postulado dogmático da conexão necessária com o texto, a tópica faz da "orientação por meio de problemas" um método por demais livre e aproxima-se do decisionismo.

O que se tenta resgatar é esse dogmatismo do direito positivo que busca apenas e tão somente na norma posta pelo estado sua base de sustentação, em detrimento dos argumentos moral e ético na busca por justiça. O que se reveste de maior importância é o ordenamento jurídico vigente, estatalmente positivado e regido por suas próprias regras extremamente formais. 
Como corolário desse cenário formal e rígido, que já não atende mais aos anseios do homem moderno é que surgem os meios alternativos de solução de conflitos, tais como a mediação, a arbitragem, conciliação, que se apresentam como coadjuvantes ao poder judiciário na tentativa de desafoga-lo. Tais institutos trazem no seu bojo não apenas uma alternativa ao tradicional modo de solução de conflitos, senão uma busca e um resgate pelos valores morais e éticos que se manifestam na atuação dos árbitros e mediadores.

Dentro do cenário desses novos institutos que surgem em nossa sociedade é que deve resplandecer a conduta do advogado como profissional de direito, pondo à prova sua postura ética e moral diante dos embates que se apresentam cada vez mais acirrados. De um lado tem o direito do cliente que patrocina; por outro lado, como adversário, a resposta da parte contrária, que também tem seu patrono advogado.

É nesse contexto que o advogado deve exercer sua árdua tarefa intelectual na defesa do seu cliente, entretanto, mantendo-se de pé e alinhado com sua crença no direito que defende e na justiça que busca, sem olvidar os valores éticos e morais que conduziram sua formação até o presente momento, ou seja, toda sua herança ética e moral que foi sendo formada no decorrer da sua trajetória terrena.

\section{A ÉTICA E A MORAL NA CONCRETIZAÇÃO DA JUSTIÇA}

Uma vez analisada a relação entre ética e moral no direito, é válido abordar o outro lado da moeda, qual seja, a ética e a moral na efetivação da justiça. Se o direito positivado, como é posto hoje, busca tão somente a norma estatizada e rigidamente formal, sem levar em conta os valores éticos e morais e dos bons costumes estabelecidos pela sociedade, vale a pena fazer uma reflexão séria sobre a contribuição da ética e da moral na realização da justiça.

Sabe-se que objeto da ética é a moral. O vocábulo moral deriva do latim, que significa "costumes", que, por sua vez, é a parte da ciência que cuida do bem, dos bons costumes essenciais à vida social do homem. É o conjunto de normas de conduta humana conforme a virtude. Portanto, percebe-se que a moral é indispensável ao 
conteúdo do direito, em especial quando se fala em concretização da prestação jurisdicional, que se dá por meio da justiça.

A ciência dos deveres é conhecida como deontologia e os princípios axiológicos que a normatizam não podem prescindir da ética. Consoante ensina o ilustre jurista Miguel Reale: "a ética é a ciência normativa da conduta". Apenas o ser humano detém esse legado, o que difere dos demais seres viventes, como já foi mencionado no início desse texto.

É válido aqui as palavras de José Renato Nalini (1997:30), que é conhecido como um dos mais importantes teóricos do estudo da ética no Brasil, que assim se expressou:

Ética é a ciência do comportamento moral dos homens em sociedade. É uma ciência, pois tem objeto próprio, leis próprias e método próprio. O objeto da ética é a moral. A moral é um dos aspectos do comportamento humano. A expressão deriva da palavra romana mores com sentido de costumes, conjunto de normas adquiridas pelo hábito reiterado de sua prática.

Portanto, pode-se depreender que a ética é a ciência que estuda os atos da conduta humana no contexto social com fundamento na lealdade bem como na decência, na lisura de atos e na dignidade da postura, de tal forma que a busca da verdade seja o alvo maior a ser alcançado, acima dos interesses pessoais escusos e das paixões. Infelizmente, o que se observa é que os interesses pessoais têm se sobrepujado aos valores morais e éticos e ao desejo real de justiça, e é essa situação que já não pode mais ser sustentada nessa sociedade da informação e globalizada.

O que não se pode esquecer é que a ética se torna, dentro desse contexto atual, uma condição indispensável para que se viva uma vida honrada nessa sociedade globalizada. Sem ética fica insustentável a vida em sociedade, e a lealdade, que é sua principal virtude, deve não apenas nortear as relações, senão passar a ser o núcleo da sua própria essência.

Não é sem razão que o estudo com a ética vem ultrapassando os milênios e as eras e já era motivo de preocupação para a erudição da Grécia antiga e clássica, cujas 
contribuições devem ser consideradas até os dias de hoje quando se trata do tema ética e moral.

Pode-se, apenas a título de exemplo, citar Aristóteles ${ }^{9}$, que admitido ainda jovem como discípulo de Platão (que aos 41 anos foi designado por Felipe da Macedônia para preceptor de Alexandre Magno) e fonte inesgotável da sabedoria humana, dedicou ao seu filho Nicômaco, nascido do seu segundo casamento do Herpile de Estagira, um dos seus trabalhos sobre a ética que ainda hoje é editado em toda parte do mundo.

Segundo Robison Barone (2012:23), em sua cartilha de ética profissional do advogado, cita o estagirista da seguinte maneira: "...este estudo não é teórico como os outros, pois estudamos não para saber o que é a virtude, mas para sermos bons, que de outra maneira não tiraríamos nenhum benefício dela" (Livro II da ética a Nicômaco).

Ainda, Miguel Reale (1994:24), outro importante jurista do cenário nacional, ensina que Aristóteles, no oitavo livro da ética a Nicômaco, desenvolve sua teoria da justiça e ele diz:

... o qualificativo de injusto se aplica a duas espécies de indivíduos: 1) àqueles que desobedecem à lei; 2) àqueles que querem receber mais que sua parte, ou seja, a parte que por direito lhes deveria ser concedida. Por oposição, o justo é o que obedece a lei e o que se contenta com sua parte.

Não se poderia deixar de lembrar o ilustre Baruch Spinoza (2010), ou Bendictus Spinoza, como ele mesmo costumava assinar em seus escritos, que também se preocupou com esse tema da ética, desenvolvendo um estilo hermético, desde a definição de Deus, passando pelos caminhos em busca da liberdade da alma à potência da razão.

Observa-se, desse modo, pelas palavras desses nobres pensadores, que a ética tem seu papel preponderante na aplicação do direito e na busca pela justiça. A teoria em demasiado, desassociado da prática, tem dificultado e atropelado os rumos do 
judiciário ao longo dos anos. Vale reiterar o que já foi falado acerca da complexidade dos temas que estão surgindo nessa sociedade globalizada.

O certo é que a história do mundo está sendo escrita em uma velocidade vertiginosa e acelerada, ao contrário das gerações passadas, onde os avanços eram dados a passos lentos, e o direito tinha condições, até certo ponto, de se sustentar e dar uma resposta adequada aos anseios dos cidadãos.

Hoje, com o avanço da ciência, as novas descobertas no campo genético, os milagres e crescimento assustador da internet, a vida gerada em laboratórios, a clonagem de seres humanos, a longevidade da vida, a fluidez das notícias, a fascinação pelo computador e a epidemia dos celulares, o homem moderno já não tem mais as mesmas certezas que seus antepassados. Agora tudo é relativo: o hoje se transmuda no ontem na rapidez de um átomo.

Dentro desse desenvolvimento todo e dessa tecnologia de ponta, a única coisa que o homem não conseguiu, até agora, foi a fórmula mágica de ser solidário consigo mesmo, de respeitar o outro homem, de não ser o pior e mais cruel predador da natureza. Infelizmente, para desencanto dessa humanidade, que se encanta com a tecnologia de ponta, e as grandes descobertas e avanço da ciência, o terror passou a ser a postura ética do outro, que age ferozmente como um animal irracional, não apenas usurpando direito alheio, mas também se enfurecendo contra qualquer que queira tutelar tais interesses.

Dentro desse contexto, entende-se que a moral e a ética são atores fundamentais para o resgate dessa sociedade corrompida e ávida por direito e justiça. Hoje, mais que nunca, urge reabilitar a ética em nossa sociedade visando trazer novamente o homem de volta à sua dignidade. Os caminhos da violência, do egoísmo, do orgulho, e da indiferença pelo seu semelhante, são os alicerces da perda da moral e da ética. Não basta reconhecer a dignidade da pessoa humana no ato normativo se a conduta pessoal vivenciada em sociedade não tem se pautado por ela. 
O certo é que a ética e a moral, uma vez resgatados, serão propulsores e direcionadores à formação de um futuro de esperança e promissor para a humanidade, que embora diante de tanta tecnologia e desenvolvimento, tem se voltado a práticas mesquinhas e primárias, que mais afastam os homens do convívio social que os integram. Eis o grande desafio que se apresenta às sociedades modernas, eis o papel da ética nesse limiar do terceiro milênio.

\section{A RELEVÂNCIA DO DIREITO PARA O HOMEM MODERNO}

A relevância que o direito desempenha na sociedade moderna está fulcralmente lidada à crise estrutural, disseminada e manifesta que descortinamos em nosso país o que acaba gerando uma cadeia desenfreada de reações as mais adversas. A falta de valores morais e éticos principiam pelos governantes que, ao invés de darem exemplo de lisura e probidade, preferem percorrer a senda oposta, ancorados sob o manto da impunidade, que revolta o cidadão que paga seus impostos e luta para manter uma vida digna e correta. Por outro turno, alguns cidadãos revoltados com essa situação resolvem agir da mesma maneira, sob a justificativa de que se o erro vem de cima não há porque não agir da mesma maneira.

Esse panorama anárquico e de caos é o que o cidadão enfrenta no seu dia a dia e não se cansa de perguntar até quando continuará assistindo a tudo isso impotente, sem perspectivas de mudanças, envolvido em uma ordem jurídica que, com seu conjunto complexo de leis estéreis, não consegue criar mecanismos de defesa desse cidadão que mantém a estrutura estatal com seus pesados impostos, sem nenhum retorno concreto. O certo é que a possibilidade ou perspectiva de alguma mudança dessa atual conjuntura deve passar por uma reflexão séria e urgente dos institutos jurídicos e sua aplicação na sociedade, que tem deixado a desejar no atendimento à prestação jurisdicional.

Há muito material escrito sobre esse tema, e a tendência, com o passar do tempo, é que mais juristas e estudiosos do direito voltem, seus olhos para essa problemática, no sentido de uma mudança de direção dos rumos que o direito tem tomado, não apenas em nossa sociedade mas, porque não dizer, no mundo como um todo, qual 
seja, o desrespeito aos interesses do cidadão que busca justiça, em detrimento dessa corrupção desenfreada que grassa e desgraça o judiciário, exatamente por conta de meros interesses pessoais.

Para o jurista Lênio Streck (2009) o direito não consegue preencher essa lacuna existente em nosso ordenamento jurídico, que perpetua a política da impunidade e o despreparo do judiciário em não atender aos anseios do cidadão, não por falta de previsão no ordenamento jurídico, senão por conta do que ele chama de uma "crise de modelo". O que o jurista gaúcho propõe é uma mudança de paradigma do atual modelo jurídico implantando em nossa sociedade, que se encontra muito distante da atual realidade vivida em nosso país.

É exatamente essa "crise de modelo" detectada pelo jurista gaúcho o divisor de água que vai conduzir a conduta do advogado nessa sociedade complexa e globalizada. Os velhos crimes repugnados pela moral primitiva do homem das cavernas voltam agora a serem cometidos com uma crueldade ainda maior. Some-se a isso outros delitos próprios da nossa geração, como os crimes eletrônicos tais como a clonagem de cartões de crédito, a movimentação criminosa de saldos bancários através de saldos eletrônicos, o envio mendaz de e-mails com links que buscam captar senhas para fins criminosos, dentre outros que só a mente humana é capaz de urdir e executar.

Pois bem, é dentro desse contexto caótico e desordenado que encontramos a relevância do direito para o homem moderno, pois o direito, na sua busca por justiça, é o centro de apreciação de todas essas angústias que inquietam o homem moderno. Desde os dramas pessoais do direito de família com sua fria higidez, até a imobilidade absoluta de nada se poder fazer diante da chacina de vidas inocentes tragadas pelas mãos de um "justiceiro" insano e sedento por vingança, o direito deve ser repensado seriamente para contemplar as mazelas sociais que emergem o homem moderno na mais completa perplexidade e impotência diante dos fatos que se presencia a cada dia na sociedade. 
A relevância do direito se faz ver na constatação da involução moral da sociedade com a conduta dos gerentes da coisa pública, que primam em fazer da lei instrumento da sua vontade, contra os interesses dos governados inábeis e ineptos de como lidar com esse problema. $O$ direito deve perpassar os interesses pessoais e ideológicos e se lançar na busca por mudanças desse cenário que ora se apresenta.

O império da força bruta tem sido o que tem prevalecido em nossa sociedade. No trato dos direitos litigiosos os pratos da balança da justiça nunca oscilam em prol do cidadão diante do estado, muito menos em favor do pobre frente ao mais abastado, ou até mesmo diante do privilegiado contra um anônimo qualquer.

Só para se ter uma pálida noção do que se fala, as regras do processo civil estabelecem privilégios em favor do ente público, com prazo quádruplo para se defender e duplo para recorrer, e isso sem mencionar que o próprio estado-juiz, na pessoa do julgador, pode recorrer de sua própria decisão toda vez que ela for proferida contra a fazenda pública.

E para piorar a situação, as reformas judiciárias que são propostas em nossa sociedade nunca são a favor do cidadão litigante comum; ao contrário, todas as reformas no Brasil tem se voltado contra o litigante, numa vã tentativa de tentar convencer a sociedade de que a justiça não é lenta e que a morosidade na prestação jurisdicional não depende apenas do próprio poder judiciário.

Tudo isso nos remonta ao atual momento em que estamos vivendo, qual seja, uma busca insaciável pela reabilitação da ética e da moral em todo o mundo, de tal modo que se tenha um padrão mínimo de conduta nos atos da vida em sociedade e, no caso da justiça, em tudo o que diz respeito aos direitos do cidadão. Advogados, juízes, promotores, todos juntos devem ser construtores de uma nova realidade jurídica, na busca constante pelos valores éticos e morais na busca pela justiça.

Institutos alternativos para solução dos conflitos como os já mencionados, quais sejam a mediação, conciliação e arbitragem, são bem-vindos nesse processo de reconstrução e busca pela justiça, uma vez que não tem a pretensão de substituição 
do poder judiciário, mas vem como coadjuvantes dessa busca por algo novo e que, de fato, preencha os ideais de justiça esquecido e deixados de lado ao longo da história.

\section{CONCLUSÃO}

Diante de tudo o que foi falado, o direito precisa abandonar essa visão dogmática e fechada que assumiu até o presente momento e deve caminhar rumo a uma visão mais plural. Nesse mundo globalizado, com todas as vertentes já apontadas, não há mais espaço para uma visão rígida, unívoca e extremamente formal, ao contrário, pode-se falar agora em multiplicidade de atores sociais (advogados, juízes, psicólogos, técnicos) e pluralismo de institutos jurídicos que melhor atenda aos anseios dessa sociedade moderna, dentre os quais a arbitragem, mediação e conciliação.

O momento atual leva à substituição da individualização do papel do juiz por um processo de co-responsabilização dos demais atores envolvidos no processo coletivo de mudanças sociais (os atores externos ao judiciário, como os profissionais retromencionados), todos unidos em busca de uma solução sólida, palpável e concreta ao atendimento das necessidades do homem atual. $\mathrm{O}$ judiciário deve fomentar e facilitar a produção de experiências que favoreçam a conexão entre si mesmo e a sociedade ao invés da disjunção, da fragmentação e afastamento do cidadão do seu anelo por justiça.

Dentro dessa nota, o próprio judiciário deve estimular as parcerias e aproximação das suas práticas jurídicas com os institutos já mencionados que, ao que se percebe pela experiência, tem conseguido dar um retorno mais adequado e satisfatório ao cidadão. Não deve existir aqui medo de competição, muito menos o receio de aparentes contradições que porventura venha a surgir em meio a esse processo de mudança. As contradições devem ser trabalhadas e não excluídas, uma vez que mesmo que algumas delas possam parecer, a priori, insuperáveis, mesmo assim elas não devem permanecer paralisadas ou estanques, sendo certo que a história da ciência é feita da construção e desconstrução de paradigmas e da superação de paradoxos. 
Portanto, para que seja possível alguma mudança há necessidade que o judiciário se abra à produção de experiências que favoreçam a multiplicidade de saberes e práticas jurídicas, estimulando a parceria, mesmo entre perspectivas e teorias divergentes do atual "status quo". Deve haver a busca pelo diálogo com os 'movimentos sociais' e outros atores que desconstroem as formas tradicionais e burocratizadas de participação do cidadão em sua própria história.

Hoje, mais que nunca, urge ao judiciário entender que papel político-social está desempenhando face aos desafios que hoje se apresentam ao homem moderno (ou pós-moderno) e tomar consciência de que toda produção de trabalho que vise mudanças estruturais tem implicações sociais, ou melhor dizendo, que toda produção de mudanças provém de determinadas e múltiplas relações de poder e de determinados campos de força.

A caminhada para o processo de mudança, aberto ao senso crítico e potencial transformador, depende do trabalho de auto-avaliação crítica do judiciário sobre o sentido e as consequências do seu modo de atuar. Há necessidade que as práticas jurídicas sejam pautadas na interação com as necessidades sociais, com os desafios da globalização, sempre fazendo um contraponto com a atual situação do judiciário, que se encontra sucateado e sem as condições mínimas de atender aos anseios do cidadão, face o excesso de demandas ali instauradas.

Por essa razão, o judiciário tem que reconhecer e legitimar outros atores que estão dispostos a contribuir para a solução dos litígios e a satisfação do cidadão. Ao invés de vislumbrar o problema de conflito de jurisdição o judiciário deveria agir no sentido de sentar à mesa com os demais profissionais sintonizados com as necessidades vitais do homem, que ultrapassam os problemas apontados e as diferenças anotadas. Isso sim, seria um gigantesco passo rumo a uma mudança ético-política, indutor e condutor da reflexão que visa não apenas uma autocrítica, mas também uma verdadeira mudança que busque colocar o direito no seu verdadeiro trilho, qual seja a busca pela justiça em meio a um mundo globalizado, sem esquecer a ética e a moral, norteadoras e pilastras de uma verdadeira sociedade Democrática de Direito. 


\section{REFERÊNCIAS}

ADEODATO, João Maurício. Ética \& Retórica. 5ª edição. São Paulo: Saraiva, 2012.

João Maurício. A legitimação pelo procedimento juridicamente organizado: notas à teoria de Niklas Luhmann. In: Ética e Retórica: Para uma Teoria da Dogmática Jurídica. p. 53-80, São Paulo: Saraiva, 2002.

BARONI, Robison. Cartilha e Ética Profissional do Advogado. 3ª ed. LTR Editora Ltda:

BOBBIO, Norberto. O positivismo jurídico: lições de filosofia do direito. Tradução de Márcio Pugliesi, Edson Bini, Carlos E. Rodrigues, São Paulo: Ícone, 1995.

. Teoria geral da política. Tradução de Daniela Beccaccia Versiani, Rio de Janeiro: Campus, 3. Reimpressão, 2000.

. Teoria do ordenamento jurídico. 10. ed. Tradução de Maria Celeste Cordeiro Leite dos Santos, Brasília: Ed. Universidade de Brasília, 1997.

CARNELUTTI, Francesco. Como nasce o Direito. Tradução de Ricardo Rodrigues Gama. 1를 Ed. Campinas: Editora Russel, 2004.

DWORKIN, Ronald. O Império do Direito. Martins Fontes: São Paulo, 2007. P. 4

FARIA, José Eduardo, Direito e Globalização Econômica - implicações e perspectivas, São Paulo: Malheiros, 2010, 1ํㅡㄹ edição, $3^{\mathfrak{a}}$ tiragem.

FERRAZ JR., Introdução ao estudo do direito: técnica, decisão, dominação. 3. ed. São Paulo: Atlas, 2001.

FILHO, Willis Santiago Guerra. Teoria da Ciência Jurídica. $2^{\mathrm{a}}$ ed. Saraiva: São Paulo, 2009.

HABERMAS, Jürgen. Direito e democracia: entre facticidade e validade. 4. ed.Vol. 1. Tradução de Flávio Beno Siebeneichler, Rio de Janeiro: Tempo Brasileiro, 1997. 3 v. 
IHERING, Rudolf Von. A Luta pelo Direito. Martin Claret: São Paulo, 2003.

KELSEN, Hans. O problema da justiça. 2. ed. Tradução de João Baptista Machado, São Paulo: Martins Fontes, 1996.

. O que é Justiça - A Justiça, o Direito e a Política no espelho da ciência. $3^{\text {a }}$ ed. São Paulo: Martins Fontes, 2001.

. Teoria geral do direito e do estado. 3. ed. Tradução de Luís Carlos Borges, São Paulo: Martins Fontes, 1998.

. TEORIA PURA DO DIREITO. Tradução João Baptista Machado. 6 ed. São Paulo: Martins Fontes, 1999, pág 1.

NALINI, José Renato. Ética Geral e Profissional. Rvista dos Tribunais: São Paulo, 1997.

NUNES, Pedro. Dicionário de Tecnologia Jurídica. $13^{a}$ ed. Renovar: Rio de Janeiro, 1998.

PERELMAN, Chaïm. Ética e Direito. Martins Fontes: São Paulo, 1996.

REALE, Miguel. Uma Nova Ética para o Juiz. Coord. De José Renato Nalini. Revista dos Tribunais: São Paulo, 1994.

SPINOZA, Baruch. A Ética. Trad. De Lívio Xavier. Ed. Tecnoprint S/A - Ediouro: São Paulo.

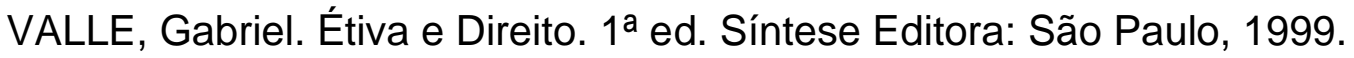

SIQUEIRA, Vicente Paulo de. Normas de Ética Profissional. Editora Jurídica Ltda: Fortaleza, 1989.

ZAFFARONI, Eugênio Raul. Poder Judiciário, crise, acertos e desacertos. Trad. De Juarez Tavares. Ed. Revista dos Tribunais: São Paulo, 1995. 